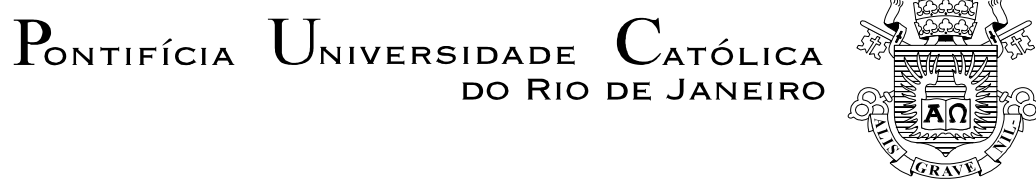

Renata Fernandes Magdaleno

Certeza não é verdade Romance policial e experiência urbana

Dissertação de Mestrado

Dissertação apresentada como requisito parcial para obtenção do grau de Mestre pelo Programa de PósGraduação em Letras do Departamento de Letras da PUC-Rio.

Orientador: Prof. Renato Cordeiro Gomes

Rio de Janeiro 


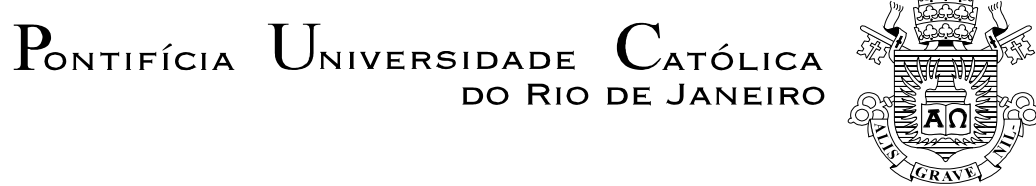

Renata Fernandes Magdaleno

\title{
Certeza não é verdade Romance policial e experiência urbana
}

\begin{abstract}
Dissertação apresentada como requisito parcial para obtenção do grau de Mestre pelo programa de PósGraduação em Letras do Departamento de Letras do Centro de Teologia e Ciências Humanas da PUC-Rio. Aprovada pela Comissão Examinadora abaixo assinada.
\end{abstract}

Prof. Renato Cordeiro Gomes Orientador Departamento de Letras - PUC-Rio

Profa. Vera Lúcia Follain de Figueiredo Departamento de Comunicação Social - PUC-Rio

Profa. Analice de Oliveira Martins CEFET/CAMPOS

Prof. Paulo Fernando Carneiro de Andrade Coordenador Setorial do Centro de Teologia e Ciências Humanas - PUC-Rio

Rio de Janeiro, de de 
Todos os direitos reservados. É proibida a reprodução total ou parcial do trabalho sem autorização da universidade, da autora e do orientador.

\section{Renata Fernandes Magdaleno}

Graduou-se em Comunicação Social na PUC-RJ em 1996. Pósgraduada em literatura brasileira pela UERJ (Universidade do Estado do Rio de Janeiro), em 1998. Trabalhou como repórter de cultura do jornal O Globo de 1998 a 2005.

Ficha Catalográfica

Magdaleno, Renata Fernandes

Certeza não é verdade Romance policial e experiência urbana / Renata Fernandes Magdaleno ; orientador: Renato Cordeiro Gomes. - 2007.

114 f. ; $30 \mathrm{~cm}$

Dissertação (Mestrado em Letras) - Pontifícia Universidade Católica do Rio de Janeiro, Rio de Janeiro, 2007.

Inclui bibliografia

1. Letras - Teses. 2. Romance policial. 3. Cidade. 4. Rio de Janeiro. 5. Gênero policial. 6. Internet. 7. Experiência urbana. 8. Garcia-Roza, Luiz Alfredo. I. Gomes, Renato Cordeiro. II. Pontifícia Universidade Católica do Rio de Janeiro. Departamento de Letras. III. Título. 


\section{Agradecimentos}

Ao meu orientador, Renato Cordeiro Gomes, pela dedicação, atenção e carinho de sempre.

Ao CNPq e à PUC-Rio, pelos auxílios concedidos, sem os quais este trabalho não poderia ter sido realizado.

À professora Pina Coco, pelo incentivo e todas as preciosas dicas.

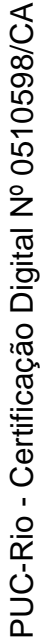

Aos colegas e professores que me ajudaram neste trajeto. 


\section{Resumo}

Magdaleno, Renata Fernandes; Gomes, Renato Cordeiro (Orientador). Certeza não é verdade Romance policial e experiência urbana. Rio de Janeiro, 2007. 114p. Dissertação de Mestrado. - Departamento de Letras, Pontifícia Universidade Católica do Rio de Janeiro.

No fim da década de 90, o mundo assistiu a um boom do romance policial. Na pós-modernidade, com a retomada dos gêneros literários, as narrativas de mistério ganham força e atingem o mercado editorial brasileiro. Mas o policial chega repaginado para o leitor. Não que os elementos da trama dedutiva ou do noir tenham desaparecido nas histórias contemporâneas, mas o formato conhecido e aceito pelo público vem sendo usado para aprofundar questões da sociedade contemporânea. A presente dissertação procura, portanto, mostrar como as narrativas policiais pensam a sociedade, enquanto lêem a cidade. Para isso, são privilegiados os livros escritos por Luiz Alfredo Garcia-Roza, com o delegado Espinosa como protagonista. Teorias sobre a vida nas metrópoles e a forma como o homem reage aos seus efeitos são articuladas na leitura das representações da cidade. O estudo começa ligando o nascimento do romance dedutivo e o surgimento do noir a grandes transformações que a sociedade e os centros urbanos sofriam naqueles momentos. E procura mostrar que a cidade é mais do que um simples cenário para as tramas se desenrolarem. Analisa a retomada do gênero na pós-modernidade e o desenvolvimento do policial no Brasil. E investiga, ainda, a presença do policial na Internet, percorrendo sites dedicados ao gênero. Tão ligada à paisagem urbana, as narrativas de mistério tomaram também o terreno virtual, aparentemente sem fronteiras.

\section{Palavras-chave}

Romance policial; cidade; experiência urbana; Rio de Janeiro; Luiz Alfredo Garcia-Roza; gênero policial e Internet. 


\section{Abstract}

Magdaleno, Renata Fernandes; Gomes, Renato Cordeiro (Advisor). Conviction isn't true: detective novels and urbanity experience. Rio de Janeiro, 2007. 114p. MSc. Dissertation. - Departamento de Letras, Pontifícia Universidade Católica do Rio de Janeiro.

In the end of 90's the world observe a boom of detective stories. In the post-modernity the literary kinds of narratives were very used again and the mystery stories were a success in the publisher market, even in Brazil, country where this kind of narrative never developed. But the detective stories, in this period, started to present some differences. Not that the classic elements weren't there, but, nowadays, they discuss aspects of the contemporary society. This work will observe how this kind of literature thinks the society and talk about the city life at the same time. The books of Luiz Alfredo Garcia-Roza, with Espinosa detective as the protagonist, were privileged in this work. Theories about the life in the contemporary cities and how people react to the effects of this kind of life were articulated with the reading of the metropolis representations. This study shows how the beginning of the detective stories were related with the big transformations that society were living in those days. The cities never were just a stage setting for the detective and his investigation. This work discuss this kind of narrative in the post-modernity and the late success in the brazilian publisher market. And, because the detective narrative was always so connected with the city, the study observed too how those stories are in internet.

\section{Keywords}

Detective novel; city; urban experience; Rio de Janeiro; Luiz Alfredo Garcia-Roza; detective narrative; Internet. 


\section{Sumário}

$\begin{array}{lr}\text { 1. Introdução } & 9\end{array}$

2. Cidade: mais do que um simples cenário $\quad 19$

2.1. As linhas retas do mapa contra o emaranhado de existências urbanas $\quad 19$

2.2. A cidade das incertezas e a narrativa policial no Brasil 33

3. A cidade de Espinosa $\quad 46$

3.1. O andar do detetive 46

3.2. Espinosa e Copacabana: Da diversidade dos habitantes à solidão dos apartamentos

3.3. Espinosa e a solidão 63

3.4. A ética do detetive $\quad 73$

4. Mistérios em cidades virtuais $\quad 87$

4.1. Uma cidade localizada no mapa? $\quad 87$

4.2. A narrativa policial no mundo sem fronteiras da Internet 94

5. Conclusão 103

Referências bibliográficas $\quad 110$ 


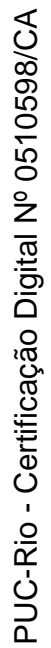

Não há mentiras nem verdades aqui Só há música urbana.

Renato Russo, "Música urbana 2” 